\title{
Environmental management of protected objects of the Eastern Podillya: Theory and practice
}

\author{
O. V. Mudrak ${ }^{1}$, G. F. Mazur ${ }^{1}$, K. H. Herasymiuk ${ }^{1}$, H. V. Mudrak $^{2}$, H. S. Tarasenko ${ }^{1}$ \\ ${ }^{1}$ Vinnytsia Academy of Continuing Education, 13 Hrushevskyi St., Vinnytsia, 21050, Ukraine, \\ ${ }^{2}$ Vinnytsia National Agrarian University, 3 Soniachna St., Vinnytsia, 21008, Ukraine \\ E-mail:ovmudrak@ukr.net
}

Received 07.11.2019 Accepted 26.12.2019

\begin{abstract}
The article deals with environmental management of the objects and territories of the Eastern Podillya Nature Reserve in the structure of the regional ecological network from the standpoint of physical and geographical zoning. A system of approaches and principles is proposed, which should be used when forming a network of protected objects. The main criterion for the selection of these objects should be the principle of representativeness, while it is advisable to take into account their three types - biotic (botanical; zoological; mycological); geographical (landscape; biogeographic); geosozological (objective; categorical; functional). The area, its size, configuration, state of internal ecological equilibrium, he qualitative and quantitative composition of the protected objects, the degree of anthropogenic impact and the types of conservation regimes play an important role in the creation of the protected objects. But also, of great importance in forming a network of protected objects is the matrix representation, which is widely used in EU countries. The basis is the landscape-zonal principle, where the matrix of biodiversity and landscapes are systems of units of natural areas (biogeographical, geobotanical, floristic, zoogeographic, physical and geographical). According to this principle, the creation of protected objects must be represented by typical (indicator) species of biodiversity, landscapes of all natural zones, subzones, regions, provinces, sub-provinces, districts. On-site surveys of the Eastern Podillya have found that a large proportion of protected sites do not fulfill the function of biodiversity and landscape diversity. The conducted field studies have shown that in the present ecological conditions of the region there is a risk of loss of this diversity. Therefore, using the principle of representativeness, we propose to optimize the nature reserve fund of Eastern Podillya from the point of view of physical and geographical zoning.
\end{abstract}

Key words: Environmental management; Nature reserve fund; Biodiversity; Landscape diversity; Ecological network; Regional network; Representativeness; Physical and geographical zoning; Eastern Podillya

\section{Introduction}

In order to preserve biotic and landscape diversity and balance the use of bioresources in their unbroken unity, it is necessary to form an ecological network. The eco-network is the only natural-territorial system, the purpose of which is to ensure ecosystem integrity, cenotic value, bio-landscape representativity through the combination of objects of the nature reserve fund (PFP) of other territories that are of special value for environmental protection, rational nature and social nature. benefits for the local population and the environmental improvement of the area. Structural elements of the national eco-network are key, connecting estorative and buffer territories. The key territories (natural nuclei, biocenters) are formed by nature conservation sites and territories (POPs). Eastern Podillya, which, along with the Dnieper, Kiev, Kirovohrad and Kharkiv regions, has the smallest PFP in Ukraine. The number of POPs (as of 5.032019 ) is 439, which is $2.52 \%$ of the total area of the region (66730,48 ha) (Classification, 2019; Environmental, 2019). The purpose of this work is to determine ways to optimize the objects and territories of the Eastern Podillya nature reserve. On the basis of the conducted researches, considering the principle of representativeness, the goal is to propose the optimization of the protected objects of the region from the positions of physical and geographical zoning.

\section{Objects of Study}

Objects and territories of the Eastern Podillya nature reserve, their ecological status, diversity, biological stability.

\section{Material and Methods}

The object of study was the landscape complexes (LC) of the protected areas, based on the materials of accounting documents and reports on scientific substantiation, literary and cartographic sources and own field studies. Directories, catalog and register of the PFP of Vinnytsia region and small rivers, determinants of geological rocks, plants and animals, the Red Book of Ukraine (flora and fauna), the Green Book of Ukraine were used. The number and area of PFP sites and territories of different categories were determined by physical and geographical zoning of the region, their ecological status, functions performed, seasonal trophic paths of animal migration, and corresponding maps were drawn up (Urushadze, Urushadze, Nahornyuk, Mudrak, Drebot, 2019; Didukha, 2009; Environmental, 2019; Mudrak, Mudrak, Razanov, Kavun, 2018). In the process of research the methods - descriptive, field, comparative, analytical, statistical, balance, expeditionary, cartographic, bioindication, biotic monitoring - were used. 


\section{Results and Discussion}

The theory and practice of forming a POET network has always been based on geographical, biotic and environmental principles. According to the classical approaches and according to the biogeographic zoning of $\mathrm{M}$. Woodward, protected areas should be located in each botanical and geographical area, representing a set of characteristic and most valuable types of vegetation and landscape complexes in the scientific field (Mudrak O, Mudrak H, Polishchuk, 2015). From the current standpoint, the concept of ecosystems should be considered as a scientific-methodological and theoretical basis of environmental activity (Mudrak, 2018). In developing such a plan, the ecosystem often needs to be considered as a territorial unit (Shelyag-Sosonko, Grodzinskiy, Romanenko, 2004). Therefore, the principle of territorial and latitudinal representation of protected objects is quite relevant.

In the EU, conservation areas are distinguished by taking into account various principles and approaches, but the principle is the principle of representativeness, which allows to preserve the size and degree of biodiversity protection. The representativeness of the POPs is a mirror image of the typical biotic and landscape diversity in the nature conservation area, which is characteristic of a certain larger area of the unit of natural geographical division (zoning). Therefore, there are three types of representativeness at present: biotic (botanical; zoological; mycological); geographical (landscape; biogeographic); geosozological (objective; categorical; functional), where not only great importance is played by the area, its size, configuration, state of internal ecological equilibrium, but the qualitative and quantitative composition of the objects of protection, the degree of anthropogenic influence and types of conservation modes also play an extremely important role. Morover, the allocation of POPs in the EU takes into account the dynamic processes of vegetation, since a significant number of animals adapt their life (habitats) to the corresponding successive stages of ecosystems. Therefore, when exogenous dynamic processes (overgrowing, marshes, onions) do not occur on minimal areas (10\% of the territory of the reserve), then there is a danger of losing these species. Matrix representativity in EU countries is based on the formation of a POPD network based on the landscape-zonal principle, where the systems of units of natural areas (biogeographic, geobotanical, floristic, zoogeographic, physical) are the matrix of biodiversity and landscapes. According to this principle, the POPs must necessarily present typical (indicator) species of biodiversity, landscapes of all natural zones, subzones, regions, provinces, sub-provinces, districts (Mudrak, Mudrak, Polishchuk, 2015; Popovych, 2007),

In Ukraine, the network of scientific and methodological and theoretical frameworks for the development of POPs was formed mainly by geobotanists. They distinguished protected objects by type of vegetation (for example, foresters distinguished forest areas, steppe scientists - steppes, gelologists - wetlands, etc.). At present, there is a tendency for a comprehensive and representative approach to the distribution of polycategorical content of POPs.

In their formation, we can use generalized systematization, which distinguishes two groups of principles and one group of approaches (Table 1 with the author's supplements), which can be replaced due to their loss of relevance (Popovych, 2007). They can help to form a single geographically representative network of POPs that should be prioritized in conservationology.

Among the scientific approaches, the most important are: 1) Rarity - obliges scientific research to preserve rare ecosystems, phytocenoses and species of flora, fauna and mycobiota, especially relics, endemics, endangered or vulnerable. Due to the rarity approach, the most valuable components of biome are primarily reserved and protected; 2 ) categorical and functional - it allows to form a single structure of complementary categories and functions of the POPs, and to develop new ones if necessary; reserve natural areas under the commandment. The categorical structure should be dynamic depending on the priority objectives of protection and changes in the functions of some of its elements; 3) conservation regime - provides for the introduction of all scientifically sound types of ecosystem conservation regimes, which is combined with the system of nature management and territorial management. This system is formed in conjunction with a unified POET system; 4) monitoring - the POPE system is formed to perform global, national, regional and local environmental tasks. It will be objective and complete only if it has an extensive network of structural elements necessary for monitoring the anthropogenic and natural processes occurring at different environmental levels of bio-organization (Mudrak, Mudrak, Polishchuk, 2015; Popovych, 2007; Shelyag-Sosonko, Grodzinskiy, Romanenko, 2004).

Table 1. System of approaches and principles used in forming a network of nature reserves and territories.

\section{Groups}

\section{Scientific approaches:}

rare;

categorical;

functional;

representative;

typological;

chologic

storage mode;

monitoring;

uniqueness;

rarities;

vulnerabilities;

values

\section{Principles:}

Scientific:

Ecological (geo-ecological landscape-ecological; hydro-ecological; urban-ecological; agroecological);

geographical

(physical-geographical-them; basin; latitudinal-measures-zonal; height-belt; geological; stratigraphic; paleontological); biotic (biogeographic; geobotanical; forest typological; zoogeographic; ecosystem; phytocenotic; evolutionary) management

\section{Natural-social:}

Cultural and educational; ethical; aesthetic; recreational (wellness; therapeutic; balneological); resource-economic

\section{Source: Author's own}

Among the basic principles for the creation and effective functioning of the POET network are the following: scientific, (ecological (environmental, environmental), geographical (biogeographic, zoogeographic, physico-geographical, landscape-ecological), evolutionary; natural and social: cultural and educational, ethical, aesthetic, recreational (health, medical, balneological), resourceeconomic, optional. Yes, landscapes envisage the creation of POPs according to the typicality and uniqueness of different ranks of 
unification of landscape units based on the characteristics and features of the classification of landscapes. For example, it is advisable to create a nature reserve or a national or local reserve, a landscape subtype - a nature reserve or a national nature park, or a regional landscape park, such as a landscape - a biosphere reserve within a façade (Popovych, 2007).

It is now advisable to use a number of approaches to form a representative POPE network. These include: geobotanical (by location of botanical areas, provinces, districts); town-planning or urban-ecological (by arrangement of elements of residential landscapes); hydrological (by the location of rivers and lakes and their basins); agro-ecological (conservation of species and genetic diversity in agro-landscapes where it is necessary to create the optimal ratio between arable land and ecological-stabilization lands - forest, meadow, marsh, water; balanced use of land reclaimed landscapes; restoration of soil-water structure of catchments, protection of small rivers and natural streams of agricultural landscapes; creation of field hydrographic network; improvement of land use structure). However, in our view, they have a significant drawback. They do not have a single structural model that can be widely applied to different territories and categories, there are no criteria and methodological bases, and there is also a consolidated amount of certain information.

These developments typically address the elements of the POPs creation either in the context of distribution by administrative districts and area (Tables 2-5), or they attach to the projected connecting territories of the latitudinal and meridional directions of the regional eco-network, which have been named but the exact position on a topographic basis for each region of Ukraine is not determined. At the same time, there is almost no attention to the 'linking' of elements of the eco-network to the physicalgeographical regions and districts. For the territory of the Eastern Podillya, a general analysis of such distribution and ways of its improvement is offered. At the same time, the principle of representativeness (not spontaneity) should be the main position in the formation of a POET network in the region from the standpoint of physical and geographical zoning (Classification, 2019; Mudrak et al., 2015; Environmental, 2019).

The analysis of the distribution of POPs, shows the uneven placement of its objects, both in quantitative composition and by category of reserves in the administrative regions of the region. It should be noted that due to the significant anthropogenic load, the landscapes of the Eastern Podillya have undergone fundamental changes over the last two centuries. Agrarian, residential and mining landscapes predominate in their structure, forest area decreased from $70 \%$ to $13.3 \%$ of the territory (slash-and-burn agriculture, industrial development). In the natural state, there are natural areas along the rivers, some dry marshes, peatlands with rare types of peat deposits, heterogeneous and erosion-rich hillsides and morphologically and lithologically diverse peaks karst relief forms with complexes of forests and onions, ancient relief forms with exits to the surface of clays (red, brown), clay green, gray, violet shales, Silurian oolitic, detrital, turtle limestone, chalk, trepel, mercury gypsum, Sarmatian sediments of limestone sand, granites (reddish and gray Precambrian origin), gneisses, etc., where forest, steppe, meadow and even wetland vegetation and ruderal communities with area of up to $5 \%$ of the area are preserved the rhetoric of the region (Mudrak, Mudrak, Polishchuk, 2015; Mudrak, Polishchuk, Vorona, Osadchuk, 2002).

The territory of the Eastern Podillya, according to Physico-geographical zoning (FGR) of Podillya, conducted by L. Voropay in 1982, belongs to the Dniester-Dnipro province, which includes 5 physico-geographical regions comprising 16 physical-geographical regions (Denysyk, 1998). The low-income areas of which the PfP are included are the northern and eastern ones, namely in the north Ulanivskyi (2 sites, 40.01 ha), Pogrebyshchenskyi (1 site - 780 ha) and Pliskivsko-Orativskyi (18 sites) area of 430.35 ha). Although in the Samgorod-Lipovetskyi district there are 15 sites of PDOs, their area is only 169.98 hectares. Within the Julin-Haivoron Physico-Geographical Area, only 5 SSPs with an area of 67.44 ha are protected. Low indicators of this area also depend on the total area, since within the region only a part of the Julin-Gayvoron district is located, and the same applies to the Pogrebischensky district. With a large number of PDOs (20 and 31), they remain small in terms of area in Vinnytsia-Dashiv and Zhmeryn districts (respectively, their area is 571 and $569.17 \mathrm{ha}$ ).

The number of POPs and their areas in other areas are better representative of the conservation of landscape complexes. At the same time, there is an uneven position of the POPs by categories. The overwhelming majority (147) of the PDOs are botanical reserves and nature sites with a total area of $12,680.51$ hectares (it is noted that over the last 20 years, local nature sites have decreased by 37, among them 30 botanicals, 5 hydrological, and 2 zoological). The most suitable for the conservation of natural landscapes are landscape reserves (15) and protected tracts (30) with a total area of 2909.1 ha. With a large number (65) of hydrological reserves and natural monuments, their area remains quite small $603.61 \mathrm{ha}$. The number of forest, general zoological, ornithological, hydrological, geological and complex reserves and gardens is quite large, both in terms of number and area and uneven location in physical and geographical areas. In addition, we investigated and mapped seasonal trophic migration paths of ungulates within the Eastern Hemisphere: European bison (Bison bonasus), elk (Alces alces), noble deer (Cervus elaphus), Far Eastern spotted deer (Cervus nipon), wild boar (Sus scrofa), European roe deer (Capreolus capreolus).

Studies have shown that deer and roe deer have small transitions within 5-15 km. Other species migrate at much greater distances. Thus, some European bison individuals met $160 \mathrm{~km}$ from their place of residence. Animal feeding is observed in the autumn and spring and is associated with changes in the forage base in individual forest tracts and adjacent agricultural landscapes. An important factor in the mammalian ancestry is the factor of concern. In general, the migration paths of these animals extend through ecological corridors - river valleys, beams, ravines, along forest strips that combine separate protected forest tracts and cottages. Animal crossing points have been formed for hundreds of years and remain permanent. At the same time animals overcome obstacles in the form of rivers, roads and railways with heavy transport load. Studies show that there are several major nomadic pathways that run across the region.

One of them stretched from the northwest (Khmelnytsky region) to the southeast (Odessa region). It can be conditionally carried out by the line Khmelnik - Shpykov - Limestone - Rudnitsa. Another from the east (Cherkasy region) to the west (Khmelnytsky region) along the line Dashiv - Bratslav - Shpykov - Dzhurin - Kopaygorod - Yaltushkiv. Along with the nomadic pathways at the regional level, there are small crossings within two or three administrative districts. Such paths have a circular or linear shape. The individual paths are interactive, linear, small in length and may not connect with others. These are the ways of rolling between the Bug-Desnyanskaya and Turbivska forest dachas, north of Vinnitsa and between the villages of Gopchytsa and Shirmivka of Pogrebyshchensky district. Their direction is related to the location of forest tracts and wetlands. As species change, nomadic pathways may change.

Thus, with the increase of the European submarine population, initially the linear path of the nomads became circular. Often individual sites are part of several migration routes. At the intersection of 2-4 paths, nodes are formed - places of temporary concentration of individual species, which are confined to individual large forest areas. Transitions of animals are observed throughout the area of forest tracts. These are the nodes in the tracts near the settlements of Dashev, Vapnyarka, Shpykov. 
Table 2. Distribution of CDAPs, archaeological and historical sites Of Eastern Podillya by administrative division (as of 05.03.2019).

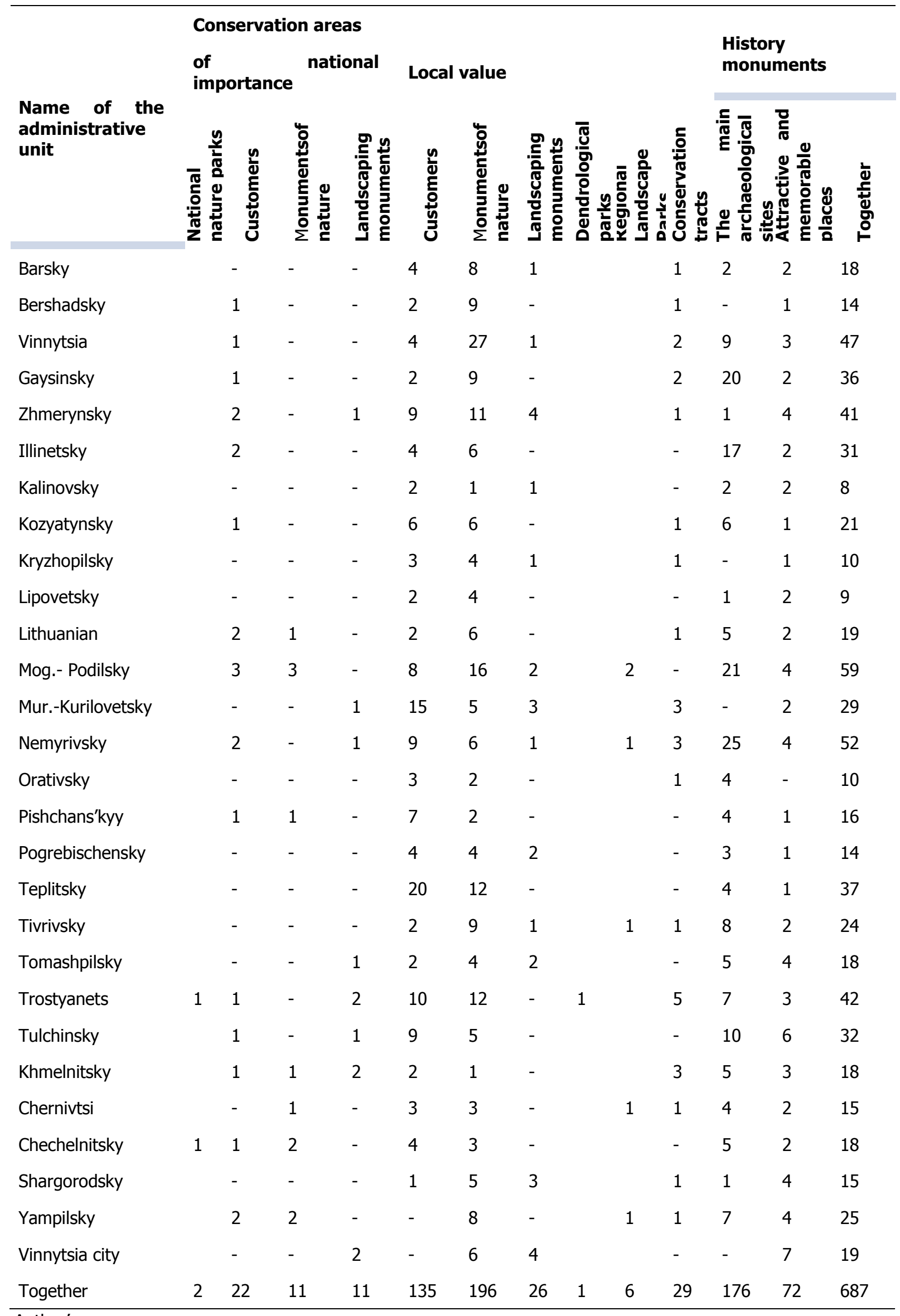

Source: Author's own.

The small width and small area of the tracts form circular nodes where the animal crossings follow a narrow strip. These include the sites near the village of Ometintsi, smt. Bratslav and Kopaygorod. The network formed by the crossing paths of ungulates of the region does not coincide with the natural corridors defined by the hydrological network (submeridial - Dnestrovsky, Buzky), nor with the corridors of distribution of phytocenoses (latitudinal - Galitsko-Slobozhansky, Stepovy). Thus, the pathways of ungulates and 
their intersections (nodes) should be considered as separate natural corridors for the distribution of biotic (genetic, population and species) diversity at regional and local level and should be taken into account in the formation and implementation of regional and local eco-networks (Mudrak, 2018; Mudrak, Tkachuk, 2019).

Table 3. Features of the distribution of the spatial-functional structure of nature reserve fund of East Podillya (as of March 5 , 2019).

\begin{tabular}{|c|c|c|c|c|c|c|c|}
\hline Number of administrative-territorial units, units & 8 & 7 & 6 & 5 & 4 & 3 & 2 \\
\hline Number of commandment categories, units & - & - & 4 & 6 & 11 & 4 & 2 \\
\hline
\end{tabular}

Source: Author's own.

Table 4. Distribution of protected sites by administrative districts in the East Podillya (as of 5.03.2019).

\begin{tabular}{|c|c|c|c|c|c|c|}
\hline Number of PFM facilities, units & $>10$ & $10-19$ & $20-29$ & $30-39$ & $40-49$ & $50-59$ \\
\hline Number of administrative-territorial units, units & 6 & 15 & 3 & 4 & - & - \\
\hline $\begin{array}{l}\text { The share of administrative and territorial units in the total } \\
\text { number of PFM facilities, } \%\end{array}$ & 1,42 & 3,53 & 0,71 & 0,95 & - & - \\
\hline
\end{tabular}

Source: Author's own

Table 5. Functional and spatial analysis of the Eastern Podillya Nature Reserve Fund by area (as of 5.03.2019).

\begin{tabular}{|c|c|c|c|c|c|c|c|c|}
\hline Area, ha & NPP & RLP & Customers & PP & Memory & PPPM & DP & Total \\
\hline$<1$ & - & - & - & 110 & - & - & - & 110 \\
\hline $1-5$ & - & - & 14 & 65 & 4 & 8 & - & 91 \\
\hline $5,1-10$ & - & - & 9 & 7 & 8 & 6 & 1 & 31 \\
\hline $10,1-25$ & - & - & 37 & 5 & 7 & 15 & - & 64 \\
\hline $25,1-50$ & - & - & 30 & 3 & 7 & 7 & - & 47 \\
\hline $50,1-100$ & - & - & 23 & 4 & 2 & 3 & - & 32 \\
\hline $100,1-250$ & - & - & 24 & 2 & 1 & - & - & 27 \\
\hline $250,1-500$ & - & - & 8 & - & - & - & - & 8 \\
\hline $500,1-1000$ & - & - & 6 & - & - & - & - & 6 \\
\hline $1000,1-2500$ & - & - & 4 & - & - & - & - & 4 \\
\hline $2500,1-5000$ & - & 2 & 2 & - & - & - & - & 4 \\
\hline $5000,1-10000$ & - & 2 & - & - & - & - & - & 2 \\
\hline $10000,1-25000$ & 1 & - & - & - & - & - & - & 1 \\
\hline Total & 1 & 4 & 157 & 196 & 29 & 39 & 1 & 427 \\
\hline
\end{tabular}

Note. National Park - National Nature Park; RLP - Regional Landscape Park; PE is a natural monument; ZU - protected area; DP Arboretum; PFSPM is a landmark art park.

Source: Author's own

\section{Conclusion}

Based on the above, in the formation of regional and local structural elements of the eco-network it is advisable to allocate large areas of area, in order to preserve landscape and biotic diversity. A more detailed survey of the territory of the region identifies separate areas that may be included in the eco-network as reference cores, natural corridors, buffer zones, recovery zones (inpatient and temporary recreation) and individual interactive elements. The following territories are proposed to be included in the elements of this network at national, regional and local levels, in addition to the general ones:

- Within Ulanivsky, Samgorod-Lipovetsky, Pogrebyshchensky FGRs, to connect the natural corridors located by the tributary rivers of the Dnieper and Southern Bug basins to identify the play areas at the source of the rivers: Gnylopyat, Guyva, Postolova, Desna, Ros, Roska Sob (watershed territories). In order to expand the territory of natural nuclei, to create a number of PFTP on the border of Samgorod-Lipovetsky, Pogrebyshchensky FGR;

- Within the Khmelnytskyi Federal Forest Service, the Southern Bug River, adjacent forests and anthropogenic territories, to create a national nature park "Central Podillya", covering an area of 46.4 thousand hectares, including as a separate nucleus the national zoological reserve of the national Zgarsky. This park will consist of three main parts of Khmelnytsky dacha, part of Letichivska valley within Vinnytsia region and Pobuzhsky Polissya. It is like three "green corridors" that will unite the protected areas that have already 
been created. The park will be located not only within Khmelnitsky, but also Vinnytsia-Dashiv FGR. The creation of a breeding and genetic center using modern biotechnologies for reproduction (reproduction), trapping and overpopulation of a European bison population, whose number is already 101, with a habitat of more than 32 thousand ha, will be appropriate in this park (Mudrak, Tkachuk, 2019).

- To design a regional landscape park (RLP) "Korostovetsky" (as a natural nucleus) within the area of Gnivansko-Haisynsky FGR; In which the outcrops of crystalline rocks to the surface of the Southern Bug River, oak-hornbeam associations, areas of steppe and wetland vegetation will be protected;

- To create a 2.2 thousand ha RLP within the Zhmerynsky Federal Forest Service to preserve the biotic diversity of wetlands, as well as to allocate a play area for the connection of natural corridors flowing through the tributaries of the Dniester and Southern Bug river basins (watersheds) territory). Particularly valuable in this area will be the preservation of water lilies (Nymphaea alba), snow white (Nymphaea candida), jugs of yellow (Nuphar lutea) and other macrophytes;

- To identify within the Vinnytsia-Dashiv FGRs the natural corridors of the Sob River and its tributaries for the migration of biocomponents between the north and south regions, as well as as separate interactive elements of ungulates. Particularly valuable for conservation in this area will be the population of the relict species of floating walnut (Trapa natans), an area of nearly 2 ha, yellow jugs (Nuphar lutea) and salvinia floating (Salvinia natans);

- in the Bershad FGR to include in the natural corridors the basins of the Trostyanets and Dohna rivers (tributaries of the Southern Bug River);

- To include the Udych River (a tributary of the Southern Bug River) in the Julian-Haivoron FGR;

- in the Kryzhopil Federal District to identify reproduction zones between the tributary rivers of the basins of the Southern Bug River and the Dniester River. These territories are natural corridors for ungulates of ungulates, where the plaque reference areas of the mixed oak and oak-hornbeam forest association will be protected;

- Create within the Yampil-Transnistrian FGR in the valley and on the terraces of the Dniester River and its tributaries, as natural nuclei, the creation of the Murafski Tovtry RLP, where the unique spurs of the Podilsky Tovtr will be protected;

- Within the Mogilev-Transnistrian FGR, in addition to the above mentioned ones, to expand as the natural core of the Dniester RLP, and then to create a biosphere bilateral reserve of the Dniester Canyon on this basis (there are unique exits of limestones that form the picturesque canyons - the Dniester Canyons - walls, various forms of weathering, geological sections, outcrops of crystalline rocks, clay shales, sandstones, chalk, limestone, small karst caves, cavities for the development of phosphorites, healing springs, meadow-vegetation, etc.) dut protected oak forests Mulberry association with oak and natural steppe vegetation.

Separation of the aforementioned territories and their protection will allow to preserve natural (semi-natural, artificial) representative phytocenotic areas within all FGRs, ensuring the preservation of the integrity of unique landscapes and multiplication of genetic, population-species, coenotic systems, floristic systems.

\section{References}

Agroforestry: Eco-balanced development: A textbook (2019). O.I. Furdychko (Ed.). Tbilisi-Kyyiv-Kherson "Hel'vetyka" (in Ukrainian). Classification of territories and objects of the nature reserve fund of Vinnytsia region. Register of Natural Reserve Fund Objects. Available from: http://www.vin.gov.ua/web/upravlinnya/web_dep_ecolog/ (in Ukrainian).

Denysyk, H.I. (1998). Pryrodnycha heohrafiya Podillya (Natural geography of Podillya). Vinnytsya: EkoBiznesTsentr (in Ukrainian). Environmental legislation of Ukraine. (2019). Available from: http://www.rada.gov.ua/ (Accessed on 10.09.2019) (in Ukrainian). Green Paper of Ukraine. (2009). Ya.P. Didukh (Ed.). Kyiv: Al'terpres (in Ukrainian).

Mudrak, H.V. (2018) Funktsionuvannya rehional'noyi ekomerezhi Skhidnoho Podillya (Functioning of the regional eco-network of East Podillya) Ahroekolohichnyy zhurnal, 3, 27-33 (in Ukrainian).

Mudrak, O.V., Polishchuk, V.S., Vorona, Ye.I., Osadchuk, I.S. (2002). Pryrodno-zapovidna merezha Vinnyts'koyi oblasti ta shlyakhy yiyi optymizatsiyi (Vinnytsia Nature Reserve Network and Ways to Optimize It). Zbirnyk naukovykh prats' Vinnyts'koho derzhavnoho ahrarnoho universytetu, 12, 50-67 (in Ukrainian).

Mudrak, O.V., Ovchynnykova, Yu.Yu. (2017). Skhidne Podillya - reprezentatyvnyy rehion natsional'noyi ekomerezhi (Eastern Podillya - a representative region of the national eco-network). Ahroekolohichnyy zhurnal, 4, 7-13 (in Ukrainian).

Mudrak, O.V., Mudrak, H.V., Razanov, S.F., Kavun, Zh.A. (2018a). Ecological-cohenological analysis of the flora Eastern Podillya as a basis for the conservation of biodiversity. Ukrainian Journal of Ecology, 8(2), 204-209 (in Ukrainian).

Mudrak, O.V., Ovchynnykova, Yu.Yu., Mudrak, G.V., Nagornyuk, O.M. (2018b). Eastern Podilia as a structural unit of a PanEuropean Environmental Network. Journal of Environmental Research, Engineering and Management, 74(3), 55-63 (in Lithuania). Mudrak, O., Ovchynnykova, Yu., Mudrak, H., Tarasenko, H. (2018c). Taxonomic and typological structure of the flora of Eastern Podilia (Ukraine). Journal of the Lithuanian Academy of Sciences. Biologija, 64(4), 285-296 (in Lithuania).

Mudrak O.V., Yelisavenko, Yu.A., Polishchuk, V.M., Mudrak, H.V. (2019). Assessment of forest ecosystems of Eastern Podillya natural reserve fund in the regional econet structure. Ukrainian Journal of Ecology, 9(1), 187-192 (in Ukrainian).

Red Book of Ukraine. Animal world (2009). I.A. Akimov (Ed.). Kyiv: Hlobalkonsaltynh (in Ukrainian).

Shelyag-Sosonko Yu.R., Grodzinskiy M.D., Romanenko V.D. (2004). Kontseptsiya, metody i kriterii sozdaniya ekoseti Ukrainy (The concept, methods and criteria for creating an ecological network of Ukraine). Kyiv: Fitosotsiotsentr (in Ukrainian).

The Red Book of Ukraine. Flora (2009). Ya.P. Didukh (Ed.). Kyiv: Hlobalkonsaltynh (in Ukrainian).

\section{Citation:}

Mudrak, O.V., Mazur, G.F., Herasymiuk, K.H., Mudrak, H.V., H.S. Tarasenko, H.S. (2019). Environmental management of reserved objects of the eastern podillya from the positions of physical-geographical regional region: theory and practice. Ukrainian Journal of Ecology, $9(4), 732-737$.

This work is licensed under a Creative Commons Attribution 4.0. License 